\title{
RPS19 wt Allele
}

National Cancer Institute

\section{Source}

National Cancer Institute. RPS19 wt Allele. NCI Thesaurus. Code C53162.

Human RPS19 wild-type allele is located in the vicinity of 19q13.2 and is approximately 11 $\mathrm{kb}$ in length. This allele, which encodes $40 \mathrm{~S}$ ribosomal protein $\mathrm{S} 19$, may play a role in both erythrocyte differentiation and protein synthesis. Mutations that result in the expression of a truncated gene are associated with Diamond-Blackfan anemia. Aberrant elevated expression of this gene is associated with some colon carcinomas. 